\title{
Release of Angiotensin Converting Enzyme by the Lung after Pseudomonas Bacteremia in Sheep
}

\author{
Arnold Bernard Gorin, Glen Hasagawa, Mannfred Hollinger, \\ JoAN SPERry, and JoAN ZuCKerman, Departments of Internal Medicine \\ and Pharmacology, University of California, Davis, California 95616
}

A B S T R A C T We studied release of angiotensin-converting enzyme (ACE) by the lung after acute injury associated with an increase in pulmonary vascular permeability. In eight adult sheep with chronic lung lymph fistulas, we measured lymph flow $\left(Q_{L}\right)$, and both ACE activity and total protein content in lymph and plasma under base-line conditions and during $24 \mathrm{~h}$ after an infusion of live pseudomonas organisms.

Under base-line conditions, ACE activity in plasma was $4.93 \pm 0.43 \mathrm{U} / \mathrm{ml}$ (mean $\pm \mathrm{SEM}$ ). The [lymph]/ [plasma] $([\mathrm{L}] /[\mathrm{P}])$ ratio for ACE was $0.93 \pm 0.18$, compared with a ratio of $0.79 \pm 0.08$ for albumin (mean $\pm S D$ ). We estimated the molecular weight of ovine ACE to be 145,000 by gel chromatography. Predicted $[\mathrm{L}] /[\mathrm{P}]$ ratio for a molecule this size is 0.51 . Thus, a substantial fraction of ACE activity detected in lung lymph under base-line conditions $(11.1 \pm 6.2 \mathrm{U} / \mathrm{h} ;$ mean $\pm \mathrm{SD})$ originated in the lung, and did not diffuse passively from plasma.

After pseudomonas infusion, endothelial injury was demonstrated by a rise in pulmonary vascular clearance for total protein $\left(\mathrm{C}_{\mathrm{TP}}=\mathrm{Q}_{\mathrm{L}} \times[\mathrm{L}] /[\mathrm{P}]\right) . \mathrm{C}_{\mathrm{TP}}=3.1 \pm 0.6$ $\mathrm{ml} / \mathrm{h}$ before pseudomonas bacteremia, and rose to 6.7 $\pm 1.2 \mathrm{ml} / \mathrm{h}$ by $2 \mathrm{~h}$ after onset of the infusion (mean $\pm \mathrm{SEM}, P<0.05)$. $\mathrm{C}_{\mathrm{TP}}$ remained significantly elevated for at least $10 \mathrm{~h}$ after the infusion. Release of ACE into lung lymph doubled after acute lung injury and equaled $22.3 \pm 13.8 \mathrm{U} / \mathrm{h}$ at $4 \mathrm{~h}$ after onset of the infusion. ACE secretion into lung lymph had returned to baseline levels by $24 \mathrm{~h}$ after bacteremia. We did not observe a significant rise in plasma ACE activity after acute lung injury.

Pseudomonas bacteremia in sheep results in acute, reversible lung injury associated with increased pulmonary vascular permeability, and increased release of

\footnotetext{
Address reprint requests to Dr. Gorin at the Department of Internal Medicine, Houston Veterans Administration Medical Center, Baylor College of Medicine, Houston, Texas 77211.

Received for publication 9 June 1980 and in revised form 9 February 1981.
}

ACE by the lung. Failure to detect a rise in plasma ACE content might result from dilution in the large vascular pool or rapid catabolism of the enzyme at some site distant from the lung.

\section{INTRODUCTION}

Endothelial injury appears to be a central event in the genesis of acute pulmonary insufficiency. In laboratory animals, a variety of insults (hemorrhagic shock, bacteremia, immune complex deposition, etc.) have been shown to cause a loss of endothelial integrity as a barrier to water and protein flux in the lung, resulting in edema formation in the presence of normal microvascular pressures (1-5). Clinically, this "noncardiogenic" pulmonary edema is documented with increasing frequency $(6-8)$.

Evidence for increased capillary porosity in certain human disease states derives largely from postmortem histological study (9). In a few cases, where the edema has been so severe that fluid-filling of airways occurred, pertracheal aspiration of this "extravascular" fluid has allowed demonstration of increased vascular permeability during life, by revealing high concentrations of plasma proteins or macromolecular tracers in the edema fluid $(7,8)$.

The loss of low molecular weight tracers (urea, ${ }^{24} \mathrm{Na}$ ) during a single passage through the pulmonary vascular bed (an adaptation of the method of Chinard and Enns (10) has been used to to estimate endothelial integrity in the lungs of man $(11,12)$. We have described and demonstrated the validity of a noninvasive measurement of pulmonary transvascular protein flux (13), and have recently reported the use of this method, external radioflux detection, in man (14).

Although these techniques may be applied to clinical assessment in patients with acute lung injury, they are technology-intensive, requiring expensive apparatus and extensive amounts of physician or technician time. The availability of a sensitive and specific, inexpensive, and noninvasive chemical means for 
determining the presence and gauging the extent of endothelial injury in lung would be clinically desirable.

Quantitation of organ-specific enzyme released into blood is a routine hospital practice. For example, measurement of serum creatine phosphokinase and lactate dehydrogenase isoenzymes after suspected myocardial infarction both confirms the diagnosis and may be used to estimate the volume of infarcted muscle $(15,16)$. In 1975, Lieberman (17) first reported that angiotensin-converting enzyme (ACE; EC 3.415.1, peptidyl dipeptidase $)^{1}$ is elevated in sera of patients with active pulmonary sarcoidosis. This finding was confirmed (18-20), and focused attention on the possibility that ACE might be a specific marker of lung injury.

More than $90 \%$ of the conversion of angiotensin I to angiotensin II (the function of ACE) occurs in the lung (21). Ryan and co-workers (22), used immunohistochemical methods to demonstrate localization of $\mathrm{ACE}$ on the luminal surface of endothelium in the pulmonary vascular bed. Acute lung injury, with an increase in microvascular permeability, might be expected to result in release of ACE into plasma by damaged endothelial cells.

We have recently shown $(23,24)$ a significant rise in serum ACE after administration of paraquat to mice and of thiourea to rats. Both agents are recognized pneumotoxins. Elevations of serum ACE were dose related, and can be shown by simple mass balance to equal the measured decrease in ACE activity in the lung homogenates from these animals. Bleomycin administration will also cause acute rise in serum ACE in rats followed by a late fall to values below baseline levels as the lung becomes fibrotic (25). In man, significant elevations of ACE have been reported in association with neonatal respiratory distress syndrome and miliary tuberculosis (but not with other forms of tuberculosis) $(26,27)$.

Gram-negative sepsis is both a recognized etiology of, and a grave complication in the adult respiratory distress syndrome associated with marked increase in mortality $(9,28)$. In the present investigation, we have measured the change in ACE activity in plasma and lung lymph after Pseudomonas bacteremia in sheep to determine whether this parameter is correlated with microvascular injury. We assessed pulmonary vascular permeability as an independent and valid index of endothelial injury.

\section{METHODS}

We prepared chronic lung lymph fistulas in eight cross-bred range sheep (age, 7-24 mo) by the method of Staub et al. (29).

\footnotetext{
${ }^{1}$ Abbreviations used in this paper: ACE, angiotensin converting enzyme; $L / P$, lymph/plasma.
}

We cannulated the efferent duct of the caudal mediastinal lymph node at least $7 \mathrm{~d}$ before study. This node drains lymph from approximately two-thirds of the total lung mass (30).

At least $2 \mathrm{~d}$ before study, we placed cannulas in the pulmonary artery and left atrium through a left thoracotomy. Cannulas were also placed in the carotid artery and internal jugular vein.

Studies were begun at a time when lymph flow and $\mathrm{L} / \mathrm{P}$ concentration ratios for total protein were in the known normal range (1). Animals were awake and were allowed free access to food and water throughout the experiment. We obtained time-matched lymph and plasma samples during a $1-h$ base-line period. We then infused $10^{7}-10^{10}$ live Pseudomonas aeruginosa organisms suspended in $60 \mathrm{ml}$ of normal saline through the jugular venous catheter over a 1-h period. Lung lymph was collected in $15-\mathrm{ml}$ heparinized graduated tubes over 30 -min intervals, and lymph flow $\left(Q_{L}\right)$ expressed as milliliters per hour. We collected time-matched plasma and lymph samples at $0.5,1,2,3,4,6,10$, 22,23 , and $24 \mathrm{~h}$ after beginning the Pseudomonas infusion. We measured ACE activity and total protein content in all lymph and plasma samples. ACE was assayed using the method of Cushman and Cheung (31). Total protein was measured by the biuret method (32). Albumin was measured by Bromcresol green adsorption (33).

We separated proteins in plasma and lymph samples by sodium dodecyl sulfate (SDS) polyacrylamide gel electrophoresis. We used 5-20\% polyacrylamide gradient gel slabs and a glycine-trisma buffer ( $\mathrm{pH} 8.8$; both gels and electrode buffer contained $0.1 \%$ SDS). Samples were diluted in an SDS (8.4\%)-glycerol-Tris buffer (pH 6.8), sample/buffer, $1: 2$, and a $5-\mu \mathrm{l}$ aliquot containing $80-100 \mathrm{mg}$ total protein was applied to the gel. Nine specimens were run on each slab $(14 \mathrm{~cm} \times 12$ $\mathrm{cm})$ : a protein standard (540-10, Sigma Chemical Co., St. Louis, Mo.) and four paired L/P samples (base line; 4, 6, and $24 \mathrm{~h}$ postbacteremia). Vertical slabs were electrophoresed at $20 \mathrm{~mA}$ constant current (Hoefer Scientific Instruments, San Francisco, Calif.) until $2 \mathrm{~h}$ after the tracking dye (bromphenol blue) exited the gel $(\sim 10 \mathrm{~h}$ total time). Gels were fixed ( $50 \%$ methanol, 7.5\% glacial acetic acid in distilled $\mathrm{H}_{2} \mathrm{O}$ ), stained with Coomassie Blue, and destained by diffusion. Gels were read with a scanning densitometer (E-C Apparatus Corp., St. Petersburg, Fla.). We quantitated protein fractions by integrating the area under each peak lying between points where the optical density equaled one-half peak optical density (full-width at half-maximum). We prepared a standard curve relating molecular weight and migration distance from the origin in the gel slab using five proteins of known molecular weights: ovine albumin, human ceruloplasmin, and pork thyroglobulin (Sigma Chemical Co.), ovine IgG (Miles Laboratories Inc. Research Products, Elkhart, Ind.), and human fibrinogen (graciously supplied by the Department of Nuclear Medicine, University of California, Davis).

We determined the approximate molecular weight of ovine ACE in lung lymph using calibrated columns packed with Bio-gel A $0.5 \mathrm{~m}(1 \mathrm{~cm} \times 30 \mathrm{~cm}$, Bio-Rad Laboratories, Richmond, Calif.) or with Sephacryl-300 (K26-100 column, Pharmacia Fine Chemicals, Div. of Pharmacia, Inc., Piscataway, N. J.). Liquid chromatography was run at $4^{\circ} \mathrm{C}$. Lung lymph was concentrated by dialyzing aliquots placed in Spectrapor dialysis tubing (mol wt cut-off 6,000-8,000, Spectrum Medical Industries Inc., Los Angeles, Calif.) against Sephadex 200 (Pharmacia Fine Chemicals Co.), before being applied to the column. Protein fractions were eluted in phosphate-buffered normal saline $(\mathrm{pH} 7.2)$ flowing at 14 $\mathrm{ml} / \mathrm{h}(1 \mathrm{~cm} \times 30-\mathrm{cm}$ column$)$ or $30 \mathrm{ml} / \mathrm{h}(\mathrm{K} \mathrm{26-100} \mathrm{column})$. 
In some runs, pooled lung lymph was first diluted with a $70 \%$ ammonium sulfate solution to obtain a final $35 \%$ ammonium sulfate concentration. This results in partial precipitation of the IgG fraction, which is the major peak of the chromatogram in the region where we found ACE activity. We found that more complete globulin removal, using higher concentrations of ammonium sulfate, resulted in a loss of significant ACE activity, perhaps by coprecipitation.

Enzyme specificity of ACE activity in plasma, lymph, and lymph fractions was demonstrated using SQ20881 (E. R. Squibb \& Sons, Inc., Princeton, N. J.), a specific inhibitor of ACE. A concentration of $1 \mu \mathrm{M}$ SQ20881 in reaction tubes completely prevented generation of hippuric acid from substrate (hippuryl-L-histidyl-L-leucine) by all samples in our assays.

We compared mean values and determined the significance of relationships between variables using standard parametric statistics (34). We accepted a $P<0.05$ as indicating statistical significance.

\section{RESULTS}

After Pseudomonas infusion, total protein clearance $([\mathrm{L}] / \mathrm{P}] \times$ lung lymph flow) $(35)$ rose, approaching a
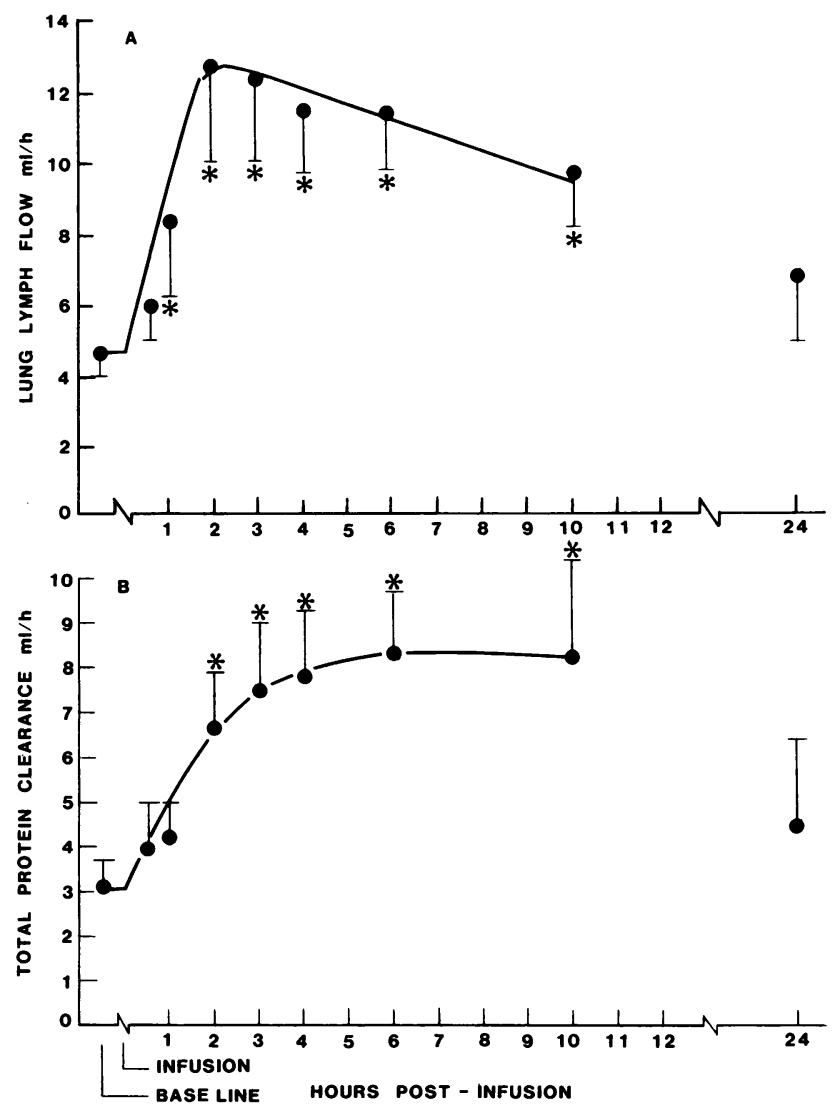

Figure 1 Lymph flow and pulmonary vascular clearance of protein after Pseudomonas bacteremia in sheep. Total protein clearance $=$ lymph flow $\times[\mathrm{L}] /[\mathrm{P}]$ for total proteins. Means of measured values in eight sheep are given \pm SEM. *indicates a significant difference in the mean $P<0.05$ when compared with the base-line value by a $t$ test for correlated means. new steady state 4-6 h after onset of the bacteremia. This indicated an increase in pulmonary vascular permeability resulting in an approximate threefold increase in pulmonary transvascular protein flow. $24 \mathrm{~h}$ after the infusion, clearance returned toward base-line values. Lymph flow also rose, reflecting both an acute and transient pulmonary hypertension and the more persistant change in vascular permeability (Fig. 1). The base-line level of ACE in ovine plasma was $4.93 \pm 0.43$ $\mathrm{U} / \mathrm{ml}$ (mean $\pm \mathrm{SEM})$.

Levels of ACE in lung lymph will vary with changing plasma ACE, with pulmonary vascular permeability, and with the release of ACE into the pulmonary interstitium by endothelial cells. The relative concentration of a plasma protein in lymph is inversely proportional to its molecular size, unless the molecule is either locally secreted or catabolized $(36,37)$. Thus, interpretation of lung lymph ACE content before and after acute lung injury requires, first of all, knowledge of the molecular dimensions of this enzyme.

Using gel filtration, we calculated a weight of 145,000 daltons for the ACE in ovine lung lymph. In Fig. 2 we

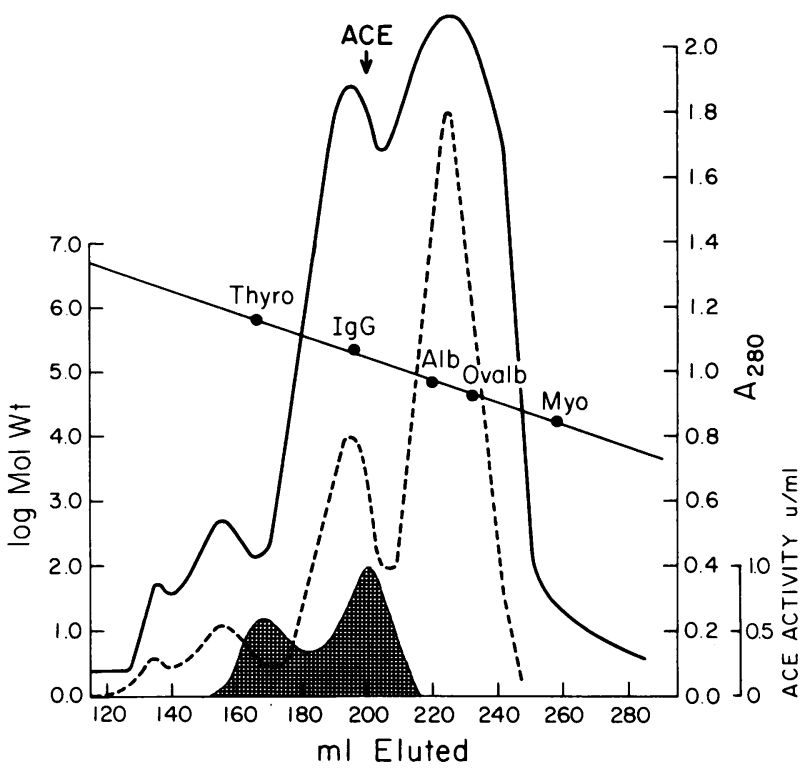

Figure 2 Determining the molecular weight of ovine ACE. Calibration curve of a $2.6 \times 100-\mathrm{cm}$ column packed with Sephacryl 300 . Proteins were eluted in phosphate-buffered saline (pH 7.2) flowing at $30 \mathrm{ml} / \mathrm{h}$. The log molecular weights of tracer proteins are shown on the abscissa (R). Thyro, thyroglobulin; Alb, albumin; Ovalb, ovalbumin; Myo, myoglobin. Absorption at $280 \mathrm{~nm}$ is also shown on the ordinate (L) for concentrated lung lymph (solid line), and for concentrated lung lymph after $1: 1$ dilution with a $70 \%\left(\mathrm{NH}_{4}\right)_{2} \mathrm{SO}_{4}$ solution resulting in partial IgG precipitation. ACE activity in the elution fractions is also indicated (shaded area). Two peaks of enzyme activity, both totally inhibited by a $1 \mu \mathrm{M}$ concentration of SQ20881, were found corresponding to molecules with weights of 145,000 and 299,000 daltons. The smaller weight was used in calculations of ACE release by lung as it yielded the more conservative values. 
show the calibration curve of a K 26-100 column packed with Sephacryl-300, indicating the elution volume in which ACE activity was localized. A similar profile of ACE activity was found using $0.5 \mathrm{~m}$ Bio-gel A. Two peaks of ACE activity are present in fractions corresponding to molecular weights of 145,000 and 299,000 . Activity of both peaks was inhibited by SQ20881. We interpreted these peaks as representing a primary molecule and its dimer.

In the 5-20\% SDS-polyacrylamide gels, we found the following relationship between molecular weight of standard proteins and distance of migration from the origin (relative migration difference, RMD, expressed relative to the migration of albumin): RMD $=4.4544-0.7175 \log \mathrm{mol} w \mathrm{t}\left(r=-0.99, \mathrm{~S}_{\mathrm{xy}}=0.0234\right.$, assuming the molecular weight of albumin $=65,000$, ceruloplasmin $=120,000, \mathrm{IgG}=156,000$, thyroglobulin subunit $=320,000$, fibrinogen $=341,000$ ). In Fig. 3 we show the gel resulting from serial dilution of a single plasma sample. Scanning gels of the 1:3 dilutions of plasma and lymph, we found four protein peaks which could be reliably identified and quantified (Fig. 4). Integrating under these peaks, the coefficient of variation in replicate samples was $<10 \%$. Peaks $I$, III, and IV are identified as albumin, IgG, and fibrinogen, respectively, by comparison with the electrophoretic mobility of the standard proteins. When indium-111, which binds with high specificity to transferrin, is added to samples before electrophoresis, all radioactivity is isolated in peak II.

In Table I we show the [L]/[P] ratio for peaks I-IV under base-line conditions, and at 4,6 , and $24 \mathrm{~h}$ after

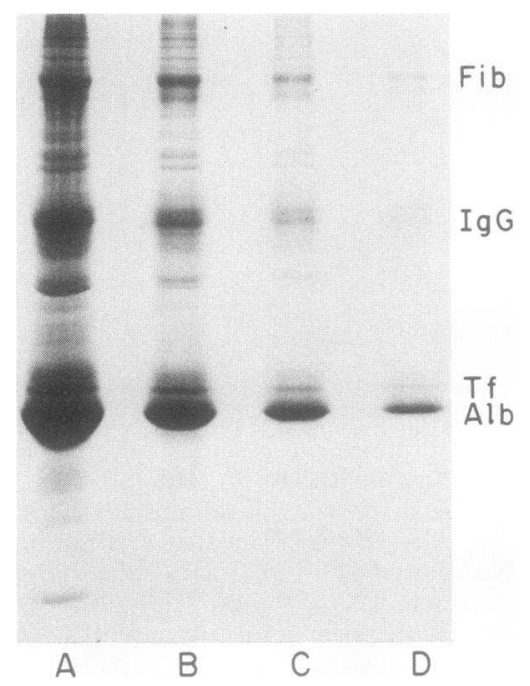

Figure 3 Polyacrylamide gradient (5-20\%) gel electrophoresis of bovine plasma. Serial dilutions of a single plasma sample are shown. A, 1:3, B, 1:9, C, 1:27, D, 1:84. The positions of bands for albumin (Alb), transferrin (TF), IgG, and fibrinogen (Fib) are shown.

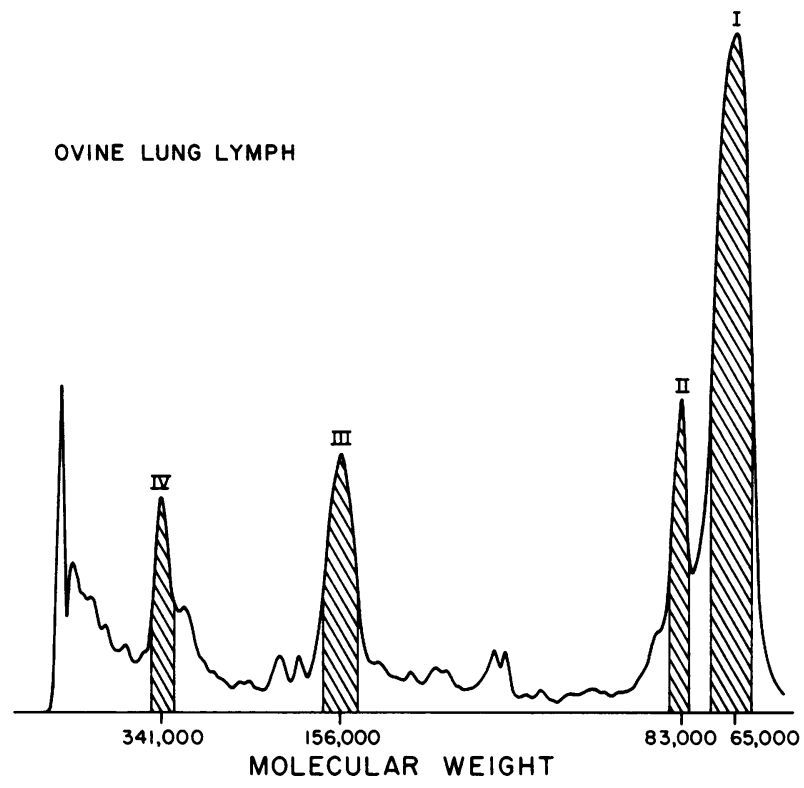

FIGURE 4 Distribution of protein content in polyacrylamide gradient gels $(5-20 \%)$. Gel is scanned after fixation and staining with Coomassie Blue. The position of four peaks reliably identified and quantified is shown (I-IV). Molecular weights were determined using known protein tracers. The shaded area under the peak is that lying between points where optical density $=0.5$ maximum for that peak (FWHM, full-width half-maximum). Normally this will contain $85 \%$ of the area under a Gaussian curve.

Pseudomonas bacteremia. In each sample (plasma or lymph), we calculated the linear regression relating log molecular weight and [L]/[P] ratio, and determined the predicted [L]/[P] for a molecule of 145,000 daltons. Regression equations derived from mean $[\mathrm{L}] /[\mathrm{P}]$ ratios are given in Table I. In five of eight studies, we found a significant decrease in the slope of the regression line at 4 and/or $6 \mathrm{~h}$ post-Pseudomonas infusion when compared with data from base-line samples $(P<0.05) .[\mathrm{L}] /[\mathrm{P}]$ ratios for peaks III and IV were significantly greater in samples obtained $6 \mathrm{~h}$ after injury than in base-line samples $(P<0.05)$.

Of the four measured peaks, only peak I did not have a symmetrical, Gaussian shape. We believe this was due to the high concentrations of albumin present even in the diluted samples (1:3). However, there was no significant difference between $[\mathrm{L}] /[\mathrm{P}]$ ratios for albumin determined electrophoretically $(0.78 \pm 0.02$, mean SEM) and by Bromcresol green absorption $(0.80 \pm 0.02$, mean SEM).

Plasma ACE levels did not change significantly following Pseudomonas infusion although a rising trend was present during the first $3 \mathrm{~h}$ after onset of bacteremia (Fig. 5). Within subjects, the peak value for ACE activity measured in plasma occurred between 1 and $3 \mathrm{~h}$ after onset of the bacteremia. A rise in 
TABLE I

Lymph:Plasma Concentration Ratios of Specific Protein Fractions*

\begin{tabular}{|c|c|c|c|c|}
\hline & \multicolumn{4}{|c|}{ Electrophoretic peak } \\
\hline & I & II & III & IV \\
\hline Molecular weight & 65,000 & 83,000 & 156,000 & 341,000 \\
\hline $\begin{array}{l}\text { Base line } \\
\quad[\mathrm{L}] /[\mathrm{P}]=4.0640-0.6888 \log \mathrm{mol} \mathrm{wt} \\
r=-0.98\end{array}$ & $0.79 \pm 0.08$ & $0.62 \pm 0.10$ & $0.50 \pm 0.16$ & $0.25 \pm 0.08$ \\
\hline $\begin{array}{l}\text { Hours after Pseudomonas infusion } \\
\begin{array}{l}4 \\
{[\mathrm{~L}] /[\mathrm{P}]=3.6183-0.6061 \log \mathrm{mol} \text { wt }} \\
r=-0.96\end{array}\end{array}$ & $0.73 \pm 0.09$ & $0.60 \pm 0.16$ & $0.46 \pm 0.09$ & $0.27 \pm 0.10$ \\
\hline $\begin{array}{l}6 \\
{[\mathrm{~L}] /[\mathrm{P}]=3.1663-0.5049 \log \mathrm{mol} w \mathrm{t}} \\
r=-0.96\end{array}$ & $0.77 \pm 0.09$ & $0.62 \pm 0.13$ & $0.58 \pm 0.12 \ddagger$ & $0.36 \pm 0.12 \ddagger$ \\
\hline $\begin{array}{l}24 \\
{[\mathrm{~L}] /[\mathrm{P}]=4.0645-0.6805 \log \mathrm{mol} \mathrm{wt}} \\
r=-0.99\end{array}$ & $0.82 \pm 0.13$ & $0.69 \pm 0.11$ & $0.52 \pm 0.17$ & $0.31 \pm 0.13$ \\
\hline
\end{tabular}
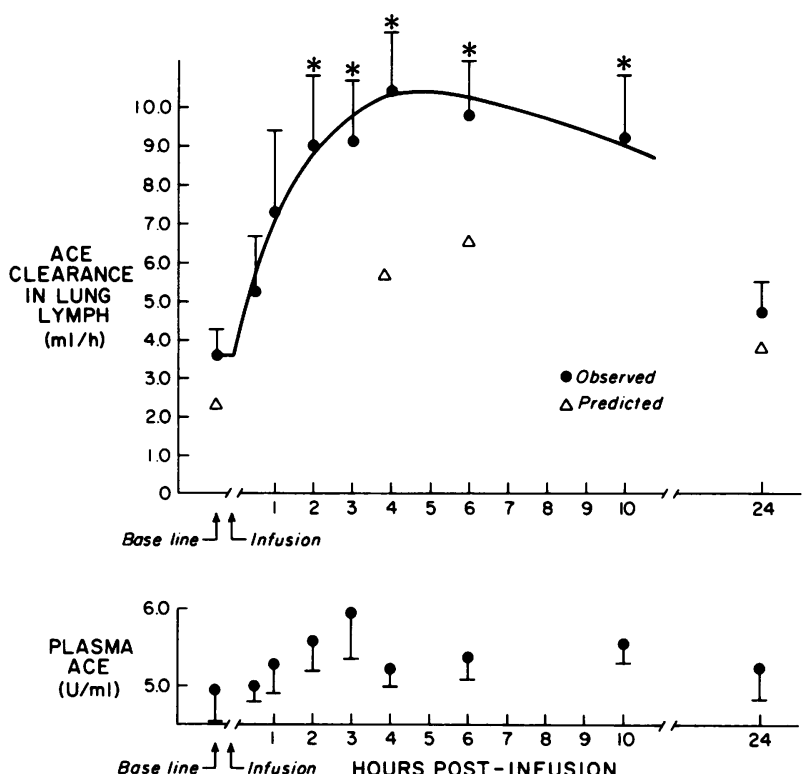

Figure 5 Pulmonary vascular clearance of ACE and plasma activity after Pseudomonas bacteremia in sheep. ACE clearance $=$ lymph flow $\times[\mathrm{L}] /[\mathrm{P}]$ for $\mathrm{ACE}$ activity. Means of observed values in eight sheep are given \pm SEM. Triangles are used to show the predicted ACE clearance based on simple diffusion from plasma. Predicted values were obtained from measurements of the clearance of other proteins (molecular weights ranging from 65,000 to 341,000 ) by the pulmonary vasculature. The lung lymph is seen to contain excess ACE both before and after Pseudomonas infusion. *, a significant different in the mean $(P<0.05$ when compared with the base-line value by a $t$ test for correlated means. plasma ACE activity after Pseudomonas infusion occurred in every animal. (When a one-tailed, rather than a two-tailed $t$ test is used for comparisons, plasma ACE levels measured $2 \mathrm{~h}$ after the onset of the bacteremia are significantly greater than base-line levels at the $P<0.05$ confidence level).

The expected ACE clearance in lung lymph under base-line conditions and at 4, 6, and $24 \mathrm{~h}$ after Pseudomonas infusion can be calculated from the measured lymph flow at these times and the $[\mathrm{L}] /[\mathrm{P}]$ ratio predicted for a molecule of $145,000 \mathrm{~mol}$ wt by the regression equations through $[\mathrm{L}] /[\mathrm{P}]$ ratios of protein fractions measured by polyacrylamide gradient gel electrophoresis. ACE clearance in lung lymph is $>75 \%$ greater than that predicted due to simple diffusion of the molecule from plasma even under base-line conditions. Although the predicted clearance of ACE rises, paralleling the changes in total protein clearance after increase in pulmonary vascular permeability, the actual delivery of ACE again exceeds that expected due to simple transvascular flux (Fig. 5).

An excess of ACE activity is measured in lung lymph both before and after acute lung injury. Differences in ACE levels in plasma and lymph might reflect real differences in enzyme concentration or some activation or inhibition of the enzyme by another molecule restricted to either the vascular or interstitial compartment. To test for this, we randomly chose six timematched plasma and lymph samples and measured ACE activity before and after mixing lymph and plasma. Unless an activator or inhibitor is present in 
only one compartment, we can accurately predict activity in the mixed samples from the activity measured in pure plasma or lymph. We found no evidence for activation of ACE in lymph, or inhibition of ACE in plasma (Table II).

Thus, the observed excess in ACE clearance is due to a release of ACE by lung into the pulmonary interstitium. The calculated quantity of ACE released into lung lymph under base-line conditions, and 4,6, and $24 \mathrm{~h}$ after Pseudomonas bacteremia is shown in Table III.

\section{DISCUSSION}

We have previously demonstrated a significant rise in serum ACE after administration of paraquat to mice and of thiourea to rats $(23,24)$. In both studies, we used doses of these agents equal to or greater than the known lethal dose, $50 \%\left(\mathrm{LD}_{50}\right)$. In this investigation, we have found that a more modest, reversible endothelial injury, sufficient to double pulmonary transvascular protein transport, results in ACE release which is detected in lung lymph, but not in plasma.

Analysis of our data is dependent on knowledge of the molecular weight of ACE. This has not previously been determined in sheep. Observations of the molecular size of ACE have varied between species, with the source of the enzyme (e.g., plasma, organ homogenates), and with the means used to determine size (38). A majority of estimates are in the range of 129,000 to 140,000 daltons (39-42). Other laboratories have suggested that ACE is an even larger molecule $(43,44)$ although the measured weights $(300,000$ and 450,000 daltons) might result from aggregation of a smaller $\sim 150,000$-dalton subunit. We found ACE activity in fractions representing molecules of 145,000 and 299,000 daltons. Greater activity was present in the 145,000-dalton fraction. Use of this estimate of molecular mass produced the more conservative cal-

TABLE II

ACE Activity in Mixed Plasma and Lymph Samples

\begin{tabular}{|c|c|c|c|c|c|}
\hline \multirow[b]{2}{*}{ Pair No. } & \multirow[b]{2}{*}{ Plasma } & \multirow[b]{2}{*}{ Lymph } & \multicolumn{2}{|c|}{ 1:1 Mixture } & \\
\hline & & & Expected & Observed & \\
\hline \multicolumn{6}{|c|}{$\mu / m l$} \\
\hline 1 & 5.52 & 6.36 & 5.94 & 6.86 & \\
\hline 2 & 2.72 & 4.31 & 3.52 & 4.85 & \\
\hline 3 & 5.02 & 6.23 & 5.63 & 6.53 & \\
\hline 4 & 3.38 & 4.14 & 3.76 & 3.39 & \\
\hline 5 & 8.07 & 8.66 & 8.36 & 6.90 & \\
\hline 6 & 3.60 & 2.84 & 3.22 & 2.97 & \\
\hline Mean & & & 5.07 & 5.25 & NS \\
\hline$\pm \mathrm{SEM}$ & & & \pm 0.80 & \pm 0.73 & \\
\hline
\end{tabular}

TABLE III

ACE Secretion into Lung Lymph (U/h)*

\begin{tabular}{cccr}
\hline & \multicolumn{3}{c}{ Hours after Pseudomonas infusion } \\
\cline { 2 - 4 } Base line & 4 & 6 & \multicolumn{1}{c}{24} \\
\hline & & $U / h$ & \\
11.1 & $22.3 \ddagger$ & $21.6 \ddagger$ & 11.2 \\
\pm 6.2 & \pm 13.8 & \pm 8.4 & \pm 10.1 \\
\hline
\end{tabular}

* Mean \pm SD of eight experiments.

$\$ P<0.05$.

culation of excess ACE in lymph. The activity of ACE in lymph was insufficient to allow isolation and purification of the soluble enzyme so that it could be further characterized. All reported isolations of ACE have always started from a whole lung homogenate or endothelial cell sonicate.

The source of plasma ACE, and the relationship of plasma and lung ACE, are unclear (38). Under baseline conditions, the $[\mathrm{L}] /[\mathrm{P}]$ ratio for $\mathrm{ACE}$ in ovine lung lymph, $0.93 \pm 0.18$, is even greater than that for albumin, $0.79 \pm 0.08$ (mean $\pm S D$ ). It is far in excess of that expected for such a large molecule reaching lymph by simple diffusion from plasma (predicted [L]/[P] $=0.51$; Table I). Thus, we found that in these sheep, $11.1 \mathrm{U} / \mathrm{h}$ of ACE activity was secreted by the lung into the effluent lymph during the base-line period. This would normally reach the vascular compartment via the thoracic duct. Lanzanillo and Fanburg (45) reported finding ACE activity in bronchoalveolar lavage fluids from normal volunteers that was 30 -fold greater than plasma activity. This again suggests release of ACE on the abluminal side of the pulmonary endothelium. But immunohistochemical studies show that ACE is localized in caveolae on the luminal surface of endothelial cells. It seems likely that in the event of cell injury far more ACE must leak directly from caveolae into the vascular lumen than could be released at the abluminal surface.

After Pseudomonas bacteremia, release of ACE into lung lymph promptly doubled, and this increase was readily detected. Yet no significant change in plasma ACE content was noted. Two possible explanations for this disparity exist.

(a) The interstitial volume of distribution of a protein macromolecule in the sheep lung is no $>50 \mathrm{ml}$ (46), while the plasma volume in our sheep is almost $2,000 \mathrm{ml}$ (47). Unless the leak of ACE directly into plasma markedly exceeds that into the pulmonary interstitium, dilution in the immense plasma pool would obscure changes readily measured in lung lymph. The coefficient of variation of replicate measurements of ACE activity in our laboratory is $6.5 \%$. More than a $13 \%$ increase in plasma ACE levels would have to be 
seen in serial samples before we could reliably say a change had occurred. Neglecting catabolism, this would require the release of $1,280 \mathrm{U}$ of ACE by the lung (even more if eventual passive diffusion into the total body interstitial pool is considered).

(b) Little is known about the catabolism of ACE. If degradation of the molecule occurs at a site distant from the lung, lymph samples are obtained without having first been processed at this site. We obtained plasma from blood samples drawn through the jugular venous catheter. ACE released into plasma might be rapidly inactivated in the peripheral vascular bed. The rise in plasma ACE activity after administration of a toxin such as paraquat or bleomycin $(24,25) \mathrm{might}$ reflect both increased release of ACE from lung endothelial cells and decreased catabolism by another injured organ. The method of Cushman and Cheung (31) measures the enzyme activity of ACE, and should not detect inactivated molecules. It is possible that a radioimmunoassay capable of detecting antigenically intact fragments of ACE would offer a more sensitive means of quantitating increased ACE leak from injured endothelium (48).

The lung vascular permeability change seen in these sheep after Pseudomonas bacteremia is of a magnitude that might, in a clinical setting, be associated with development of noncardiogenic pulmonary edema. The lesion typically regresses over $24-48 \mathrm{~h}$ (1). This time-course suggests "healing" and normalization of injured endothelial cells, rather than replacement of a population of irreparable or dead cells (49). Our data show that ACE is released by lung endothelium under base-line conditions and after injury, and that release is not simply an indicator of cell death.

Although our animals suffered a significant loss of endothelial integrity, we did not see a correlated rise in plasma ACE levels. Yet, ACE activity certainly increases in plasma if lung injury is sufficiently massive $(23,24)$. Ability to detect an increase in plasma ACE probably depends upon the severity of the vascular insult, and on factors effecting catabolism of the enzyme in vivo. Measurement of plasma ACE levels in acute lung injury may have value as a prognostic indicator of the probability that the lung endothelium will ever recover normal function.

\section{ACKNOWLEDGMENT}

This study was supported by grant ES02093-02 from the National Institute of Environmental Health and Safety.

\section{REFERENCES}

1. Brigham, K. L., W. C. Woolverton, L. H. Blake, and N. C. Staub. 1974. Increased sheep lung vascular permeability caused by pseudomonas bacteremia. J. Clin. Invest. 54: 792-804.

2. Todd, T. R. J., E. Baile, and J. C. Hogg. 1978. Pulmonary capillary permeability during hemorrhagic shock. J. Appl. Physiol. Respir. Environ. Exercise Physiol. 45: 298-306.

3. Scherzer, H., and P. A. Ward. 1978. Lung and dermal vascular injury produced by preformed immune complexes. Am. Rev. Respir. Dis. 117: 551-557.

4. Jones, J. G., M. Berry, G. H. Hulands, and J. C. W. Crawley. 1978. The time course and degree of change in alveolocapillary membrane permeability induced by aspiration of hydrochloric acid and hypotonic saline. Am. Rev. Respir. Dis. 118: 1007-1014.

5. DeFouw, D. O., and P. B. Berendsen. 1979. A morphometric analysis of isolated perfused dog lungs after acute oncotic edema. Microvasc. Res. 17: 90-103.

6. Hopewell, P. C., and J. F. Murray. 1976. The adult respiratory syndrome. Annu. Rev. Med. 27: 343-356.

7. Fein, A., R. F. Grossman, J. G. Jones, E. Overland, L. Pitts, J. F. Murray, and N. C. Staub. 1979. The value of edema fluid protein measurement in patients with pulmonary edema. Am. J. Med. 67: 32-38.

8. Anderson, R. R., R. L. Holliday, A. A. Driedger, M. Lefcoe, B. Reid, and W. J. Sibbald. 1979. Documentation of pulmonary capillary permeability in the adult respiratory distress syndrome accompanying human sepsis. Am. Rev. Respir. Dis. 119: 869-877.

9. Bachofen, M., and E. R. Weibel. 1977. Alterations of the gas exchange apparatus in adult respiratory insufficiency associated with septicemia. Am. Rev. Respir. Dis. 116: $589-615$.

10. Chinard, F. O., and T. Enns. 1954. Transcapillary pulmonary exchange of water in the dog. Am. J. Physiol. 178: 197-202.

11. Gump, F. E., Y. Mashima, S. Jorgensen, and J. M. Kinney. 1971. Simultaneous use of three indicators to evaluate pulmonary capillary damage in man. Surgery. 70: 262269.

12. Brigham, K. L., J. D. Snell, Jr., T. R. Harris, S. Marshall, J. Haynes, R. E. Bowers, and J. Perry. 1979. Indicator dilution lung water and vascular permeability in humans: effects of pulmonary vascular pressure. Circ. Res. 44: 523-530.

13. Gorin, A. B., W. J. Weidner, R. N. Demling, and N. C. Staub. 1978. Non-invasive measurement of pulmonary transvascular protein flux in sheep. J. Appl. Physiol. 45: 225-233.

14. Gorin, A. B., J. P. Kohler, and G. DeNardo. 1980. Noninvasive measurement of pulmonary transvascular protein flux in normal man. J. Clin. Invest. 66: 869-877.

15. Sheil, W. E., J. K. Kjekshus, and B. E. Sobel. 1971. Quantitative assessment of the extent of myocardial infarction in the conscious dog by means of analysis of serial changes in serum creatine phosphokinase activity. J. Clin. Invest. 50: 2614-2625.

16. Sheil, W. E., J. F. Lavelle, J. W. Covell, and B. E. Sobel. 1973. Early estimation of myocardial damage in conscious dogs and patients with evolving acute myocardial infarction. J. Clin. Invest. 52: 2579-2590.

17. Lieberman, J. 1975. Elevation of serum angiotensin converting enzyme (ACE) levels in sarcoidosis. Am. J. Med. 59: 365-372.

18. Fanburg, B. L., M. D. Schoenberger, B. Bachus, and G. K. Snider. 1976. Elevated serum angiotensin I converting enzyme in sarcoidois. Am. Rev. Respir. Dis. 114: 525-528.

19. Studdy, P., R. Bird, and D. G. James. 1978. Serum angiotensin converting enzyme (SACE) in sarcoid and other granulomatous disorders. Lancet. II: 13311334.

20. Ueda, E., T. Kawabe, T. Tachibana, and T. Kokubu. 1980. 
Serum angiotensin converting enzyme activity as an indicator of prognosis in sarcoidosis. Am. Rev. Respir. Dis. 121: $667-671$.

21. Ng, K. K. F., and J. R. Vane. 1967. Conversion of angiotensin I to angiotensin II. Nature (Lond.). 216: 762-766.

22. Ryan, J. W., U. S. Ryan, D. R. Schultz, G. Whitaker, and A. Chung. 1975. Subcellular localization of pulmonary angiotensin converting enzyme (kinase II). Biochem. J. 146: $497-499$.

23. Hollinger M. A., S. N. Giri, S. Patwell, J. E. Zuckerman, A. Gorin, and G. Parsons. 1980. Effect of acute lung injury on angiotensin converting enzyme in serum, lung lavage, and effusate. Am. Rev. Respir. Dis. 121: 373-376.

24. Hollinger, M. A., S. W. Patwell, J. E. Zuckerman, A. B. Gorin, G. Parsons, and S. N. Giri. 1980. Effect of paraquat on serum angiotensin converting enzyme. Am. Rev. Respir. Dis. 212: 795-798.

25. Vats, T. S., A. Molteni, L. Mattioli, and R. Barth. 1979. Serum and lung angiotensin I converting enzyme as a predictor of bleomycin induced pulmonary fibrosis in mice. Am. Rev. Respir. Dis. 119(Suppl.): 85 (Abstr.).

26. Mattiolli, A., R. M. Zakheim, K. Mullis, and A. Molteni. 1975. Angiotensin I-converting enzyme activity in idiopathic respiratory distress syndrome of the newborn infant and in experimental alveolar hypoxia in mice. J. Pediatr. 87: 97-101.

27. Thomas, A. V., A. Ansari, M. Khurana, and A. H. Niden. 1979. Elevated serum angiotensin converting enzyme in miliary tuberculosis. Am. Rev. Respir. Dis. 119(Suppl.): 97 (Abstr.).

28. George, H. A., M. F. Clowes, E. Hirsch, L. Williams, E. Kwasnik, T. F. O’Donnell, P. Cuevas, V. K. Saini, I. Moradi, M. Farizan, C. Saravis, M. Stone, and J. Kuffler. 1975. Septic lung and shock lung in man. Ann. Surg. 181: $681-692$.

29. Staub, N. C., R. D. Bland, K. L. Brigham, R. Demling, A. J. Erdmann, and W. C. Woolverton. 1975. Preparation of chronic lung lymph fistulas in sheep. J. Surg. Res. 19: 315-320.

30. Staub, N. C. 1974. Pulmonary edema. Physiol. Rev. 54: 678-811.

31. Cushman, D. W., and H. S. Cheung. 1971. Spectrophotometric assay and properties of the angiotensin converting enzyme of rabbit lung. Biochem. Pharmacol. 20: $1637-1648$.

32. Gornall, A. G., C. S. Bardawill, and M. M. David. 1949. Determination of serum proteins by means of the biuret reaction. J. Biol. Chem. 177: 751-766.

33. Doumas B. P., W. Watson, and H. G. Briggs. 1971. Albumin standards and the measurement of serum albumin with bromocresol green. Clin. Chim. Acta. 31: 87-96.

34. Snedecor, G. W., and W. G. Cochran. 1967. In Statistical Methods. Iowa Iowa State University Press, Ames, Iowa.
35. Brigham, K., and P. Owen. 1975. Mechanism of the serotonin effect on lung transvascular fluid and protein movement in awake sheep. Circ. Res. 36: 761-770.

36. Vaerman, J. P., and J. F. Heremans. 1970. Origin and molecular size of immunoglobulin- $A$ in the mesenteric lymph of the dog. Immunology. 18: 27-38.

37. Gorin, A. B., and J. Gould. 1974. Immunoglobulin synthesis in the lungs and caudal mediastinal lymph node of sheep. J. Immunol. 123: 1339-1342.

38. Longenecker, G. L., and C. G. Huggins. 1977. Biochemistry of the pulmonary angiotensin-converting enzyme. In Metabolic Functions of the Lung. Y. S. Bakhle and J. R. Vane, editors. Marcel Dekker, Inc., New York. 55-83.

39. Lee, H. J., J. N. Larue, and I. B. Wilson. 1971. Angiotensin converting enzyme from guinea pig and hog lung. Biochim. Biophys. Acta. 250: 549-557.

40. Lanzillo, J. J., and B. L. Fanburg. 1974. Membranebound angiotensin-converting enzyme from rat lung. J. Biol. Chem. 249: 2312-2318.

41. Das, M., and R. L. Soffer. 1975. Pulmonary angiotensinconverting enzyme: structural and catalytic properties. J. Biol. Chem. 250: 6762-6768.

42. Hial, V., M. A. Gimbrone, Jr., M. P. Peyton, G. M. Wilcox, and J. J. Pisano. 1979. Angiotensin metabolism by cultured human vascular endothelial and smooth muscle cells. Microvasc. Res. 17: 314-329.

43. Dorer, F. E., J. R. Kahn, K. E. Lentz, M. Levine, and L. T. Skeggs. 1972. Purification and properties of angiotensinconverting enzyme from hog lung. Circ. Res. 31: 356-366.

44. Nishimura, K., N. Yoshida, K. Hiwada, E. Ueda, and T. Kokubu. 1978. Purification and properties of angiotensin I-converting enzyme from human lung. Jpn. Circ. J. 42: 639-640.

45. Lanzanillo, J. J., and B. L. Fanburg. 1979. Angiotensin converting enzyme in bronchoalveolar lining fluid. Lancet. I: $1199-1200$.

46. Selinger, S. L., R. D. Bland, R. H. Demling, and N. C. Staub. 1975. Distribution volumes of $\left[{ }^{131} \mathrm{I}\right]$ albumin, $\left[{ }^{14} \mathrm{C}\right]$ sucrose, and ${ }^{36} \mathrm{Cl}$ in sheep lung. J. Appl. Physiol. 39: 773-779.

47. Gorin, A. B., and P. A. Stewart. 1979. Differential permeability of endothelial and epithelial barriers to albumin flux. J. Appl. Physiol. 47: 1315-1324.

48. Soffer, D. M. 1976. RL: Pulmonary angiotensin-converting enzyme antienzyme antibody. Biochemistry. 15: 5088-5094.

49. Elemer, G., T. Kerenyi, and H. Jellinek. 1976. Scanning (SEM) and transmission (TEM) electronmicroscopic studies on post-ischemic endothelial lesions following recirculation. Atherosclerosis. 24: 219-232. 